\title{
CHEMICALS COMPOUNDS EMITTED BY COMMERCIAL PLANTATION AND THEIR RELATIONSHIP WITH THE LOCAL TROPOSPHERIC CHEMISTRY
}

\section{COMPOSTOS QUÍMICOS EMITIDOS POR PLANTIO COMERCIAL E SUA RELAÇÃO COM A QUÍMICA TROPOSFÉRICA LOCAL}

\author{
Ana Paula dos Santos Zepka ${ }^{1}$
}

\begin{abstract}
Eucalyptus stands are among the most commonly used species for reforestation in the "Vale do Paraíba". The objective of this study was to detect for the first time isoprene emission by commercial plantations of eucalyptus and relate it to the local tropospheric ozone, thus evaluating the environmental impact of these forests. The samples were collected from denuders of Air Toxics analyzed by gas chromatography through thermal desorption. Ozone was monitored by UV Photometric $\mathrm{O}_{3}$ Analyzer Model 49i. There were two field trials: one in the summer of 2010 and another in the winter of 2011, in the city of Caçapava, São Paulo state. At midday, the highest mixing ratios were detected of isoprene, ranging from a maximum of 8.3 ppbv on November 29, 2010 to 3.5 ppbv on June 30, 2011. Also at midday, the air temperature and photosynthetic active radiation were higher: $33.7^{\circ} \mathrm{C}$ and $2243 \mu \mathrm{mol} \mathrm{s}{ }^{-1}$ and $18^{\circ} \mathrm{C}$ and $387 \mu \mathrm{mol} \mathrm{s} \mathrm{s}^{-1}$, respectively. The decrease observed in winter weather parameters directly influence isoprene emission which was $65 \%$ lower than in weeks of the summer study. The ozone introduced a maximum delayed peak about two hours later than a maximum of isoprene, which is justifiable due to the time required for this gas to react with other precursors and ozone forms. Considering the maximum detected ozone (27.9 ppbv), the atmosphere in this region is considered clean in accordance with the CONAMA.
\end{abstract} Keywords: eucalyptus; isoprene; ozone.

Resumo: Dentre as espécies mais utilizadas para reflorestamento na região do Vale do Paraíba, destaca-se o eucalipto. O objetivo deste trabalho foi o de detectar, pela primeira vez, a emissão do gás isopreno por plantações comerciais de eucalipto e relacioná-la ao ozônio troposférico local, avaliando, assim, o impacto ambiental dessas florestas. As amostras foram coletadas em 'denuders Air Toxics' analisados por cromatografia gasosa via dessorção térmica. 0 ozônio foi monitorado pelo Analisador 'UV Photometric' 03 Modelo 49i. Foram realizadas duas campanhas intensivas: uma no verão de 2010 e outra no inverno de 2011, na cidade de Caçapava, estado de São Paulo. Ao meio-dia, foram detectadas as maiores razões de mistura de isopreno, variando do máximo de 8,3 ppbv, em 29 de novembro de 2010, a 3,5 ppbv, em 30 de junho de 2011. Também ao meio-dia, a temperatura do ar e a radiação fotossinteticamente ativa foram maiores: $33,7^{\circ} \mathrm{C}$ e $2243 \mu \mathrm{mol} s-1$ e $18^{\circ} \mathrm{C}$ e $387 \mu \mathrm{mol} \mathrm{s}-1$, respectivamente. A diminuição observada nos parâmetros meteorológicos do inverno influenciou, diretamente, numa emissão de isopreno $65 \%$ menor do que na semana estudada do verão. $O$ ozônio apresentou pico máximo atrasado, cerca de duas horas em relação ao máximo de isopreno, o que é justificável devido ao tempo necessário para que esse gás reaja com outros precursores e forme ozônio. Considerando o máximo detectado de ozônio (27,9 ppbv), conclui-se que a atmosfera dessa região é considerada limpa de acordo com o CONAMA.

Palavras-chave: eucalipto; isopreno; ozônio.

${ }^{1}$ Doutora em Geofísica Espacial - Instituto Nacional de Pesquisas Espaciais - INPE. E-mail: anazepka@gmail.com. 


\section{INTRODUCTION}

Eucalyptus (Eucalyptus sp.) is one of the main species used in reforestation of degraded areas, due to its rapid growth, low nutrient requirement and wide application in the timber industry (CAMPINHOS JR., 1999). The commercial plantations with fast growing species can provide adequate protection to critical areas, assisting in the stabilization of dunes, control of erosion, operation of the catchment areas and the recovery of mining areas (LIMA, 1990).

Brazil is the world's largest producer of pulp (MORA; GARCIA, 2000), with the area reforested eucalyptus growing (FLYNN; SHIELD, 1999). The average annual growth in Brazil is $66 \%$ higher than the United States and $38 \%$ in South Africa, respectively (FIBRIA, personal communication, 2012). However, there are still uncertainties about the environmental impact that such species can cause to the environment in relation to the impoverishment and dryness of the soil, besides the contribution to the enhanced greenhouse effect. In the current scenario of global climate change, issues such as reforestation programs and expansion of commercial forests are increasingly debated and therefore studies that provide an understanding of the consequences caused by this activity are necessary.

In São Paulo, until now, there is no research about chemical compounds emitted by eucalyptus plantations, although this state stand out in this commercial business, especially in the "Vale do Paraíba", with 88.000 hectares producing 46 million seedlings per year. In this work, the region chosen for data collection was Company Fibria Paper and Pulp, in the city of Caçapava, because this is an area heavily exploited for reforestation and not yet investigated in contributing to air pollution.

It is known that forests emit greenhouse gases, among which stand out volatile organic compounds (VOCs), important reagents that in the presence of solar radiation, leading to ozone formation when combined with the nitrogen oxides (NOx), highly reactive species present in the troposphere (GUENTHER et al., 1995). These compounds may be products of different physiological processes produced in various tissues and compartments of the plant (KESSELMEIER et al., 2002), being released into the atmosphere as a defense mechanism against attack by herbivores and also against the invasion of other plant species, the weeds (TINGEY; TURNER; WEBER, 1991). Among the most important biogenic $\mathrm{VOC}_{\mathrm{s}}$, isoprene $\left(\mathrm{C}_{5} \mathrm{H}_{8}\right)$ is the most abundant, found in the troposphere at a mixing ratio of from 0,2 to 30 ppbv (SEINFELD; PANDIS, 1998).

Increased $\mathrm{VOC}_{s}$ emissions could have profound impact on regional ozone chemistry (SINGH et al., 2011). Ozone is an important greenhouse gas and air pollutant. In Brazil, legislation CONAMA (National Environment Council), provides a maximum of 81,5 ppbv ozone, considering the national standards for air quality (PQA) determined by Regulatory Decree $n^{\circ} 348$ of 1990 IBAMA and processed in CONAMA Resolution $n^{\circ} 003 / 90$ (CETESB, 2009). Values above the stipulated qualify the air as polluted.

In tropical areas such as Brazil, for example, isoprene is the dominant compound resulting from the combination of high temperature and high density of biomass (SHARKEY et al., 2001). The biogenic emissions of isoprene can lead to the formation and growth of organic aerosols in forest areas and also in industrial regions (LACK et al., 2004; VOLKAMER et al., 2006; FARINA et al., 
2010).

For more than five decades, it was proposed that foliar emissions of VOCs from trees and other vegetation have significant effect on the chemistry of Earth's atmosphere (WENT, 1960). Studies on greenhouse gas emissions by plants show that half or more of the mass of VOCs emitted by vegetation consists of isoprene (PLACET et al., 1990), characterized as the only biogenic hydrocarbon related to photosynthetic activity of plants (SINGH; ZIMMERMAN, 1992).

The isoprene is one of the most abundant compounds in the tropics, where weather conditions favor the production of this compound by the plant and its subsequent release to the atmosphere (TINGEY; TURNER; WEBER, 1991; HARLEY et al., 2004). Such emissions are directly related to solar radiation and air temperature, since essentially no isoprene is emitted without illumination (WINER et al., 1989). Tropical forests account for approximately half of the global emission of VOCs (GUENTHER; MONSON; FALL, 1991).

The global scientific community has struggled to understand the effects of emissions of volatile organic compounds in general and also of isoprene in the atmosphere. Due to the absence of such research in the study area, the objective of this study was to evaluate for the first time, the emission of isoprene by commercial planting of eucalyptus and associate to tropospheric ozone, considering the weather conditions prevailing in the city of Caçapava, São Paulo state.

\section{MATERIAL AND METHODS}

Gases were collected in commercial plantations of eucalyptus Fibria ( $23^{\circ} 07^{\prime} \mathrm{S}, 45^{\circ} 37^{\prime} \mathrm{O}, 625$ meters) in "Vale do Paraíba", Caçapava city, São Paulo state. There were two field campaigns: one in the summer 2010 and another in the winter 2011, with five and three days each, respectively. The specie considered was Eucalyptus urophylla S.T. Blake.

Ozone was monitored by UV Photometric $\mathrm{O}_{3}$ Analyzer Model 49i with average flow 1 to $3 \mathrm{~L}$ $\mathrm{min}^{-1}$ and mixing ratio from 0,05 to $200 \mathrm{ppbv}$. The isoprene was collected in denuders Air Toxics, typical for the capture of this gas due to its graphitized black carbon filler, specific for the adsorption of hydrocarbon. The denuders were coupled to portable air pump that captured five liters of air in each sample. The total amount of sampled air (by volume) was determined from the product of the average flow of air collected by the sampling time. Each denuder was pre-concentrated via thermal desorption and subsequently analyzed by gas chromatography with flame ionization detection (ATD/GC/FID) (PERKINELMER, 2005). 50, 60 and $70 \mathrm{~mL}$ of standard gas were used for construction of calibration curves obtained that the relative precision of $2,8 \%$. The standard used was $99 \pm 10$ ppbv n-butane (normal butane) e $84 \pm 8$ ppbv isoprene in ultrapure nitrogen.

The experiment was carried out based on the criteria according to the USEPA $(1997 ; 1999)$ and qualified according Method TO-15 and 17. In this work has been met the following criteria: limit of detection (LD) of the method $\leq 0,5$ ppbv, accuracy of analytical duplicates within $20 \%$ standard gas samples and $30 \%$ by mixing ratios normally expected of air samples (0,5 to 2 pbbv). Was obtained a LD of $0,31 \mathrm{ppbv}$ for isoprene, an analytical precision of the duplicates of $15 \%$ and an accuracy of $21 \%$ calculated on each sampling day, considering the area of isoprene to default values and observed. 
A station located at the Fibria company, and distant about 2 miles from the point of collection, provided meteorological parameters. Data were recorded every 15 minutes.

\section{RESULTS AND DISCUSSION}

The mixing ratio of isoprene obtained in the first intensive campaign is shown in Figure 1.

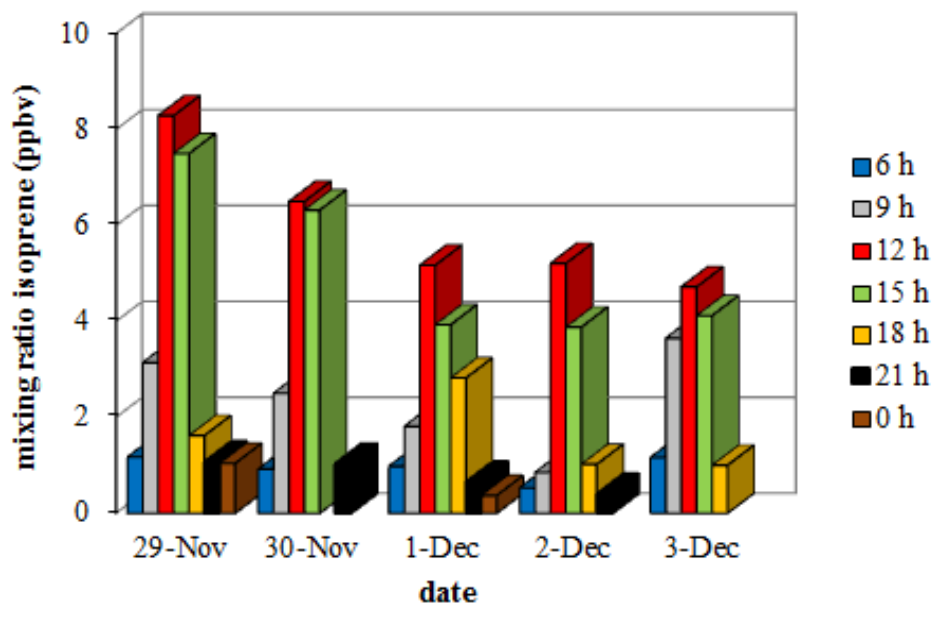

\section{Figure 1 - Mixing ratio of isoprene at each time of collection during the first intensive campaign (2010) in Fibria.}

Is observed in Figure 1 that the maximum mixing ratios of isoprene measured during five-day interval was detected at midday, with a higher value (8,3 ppbv) on November 29, 2010. From 21 hours, the mixing ratio reached an average of $0,8 \mathrm{ppbv}$ and decreased at night, showing the lowest value in the evening. This result confirms the predicted by Harley et al. (2004) that is a strong dependence of solar radiation on isoprene emissions by eucalyptus. Rizzo (2006) with samples collected in the Amazon in the summer of 2004 noted that in the early afternoon isoprene peaked at $7,8 \mathrm{ppbv}$ and at night, $0,7 \mathrm{ppbv}$, indicating the mixing ratio similar to that detected during the night in this work.

Isoprene is considered a photochemically active compound because the synthesis of isoprene synthase enzyme which produces it is stimulated by high temperatures and decreased at higher concentrations of $\mathrm{O} 3$. The gene expression IspS (essential to the synthesis of isoprene synthase) is stimulated during heat and affected by the presence of ozone (FARES et al., 2006). Fuentes et al. (2000) created the hypothesis that the isoprene synthase is an enzyme catalyzed by light, so that the isoprene emission is dependent on the solar radiation. Thus, this compound shows a greater variation of concentration during the afternoon compared to night, when analyzing the behavior all day long.

The mixing ratio of isoprene detected in the second intensive campaign is shown in Figure 2. 


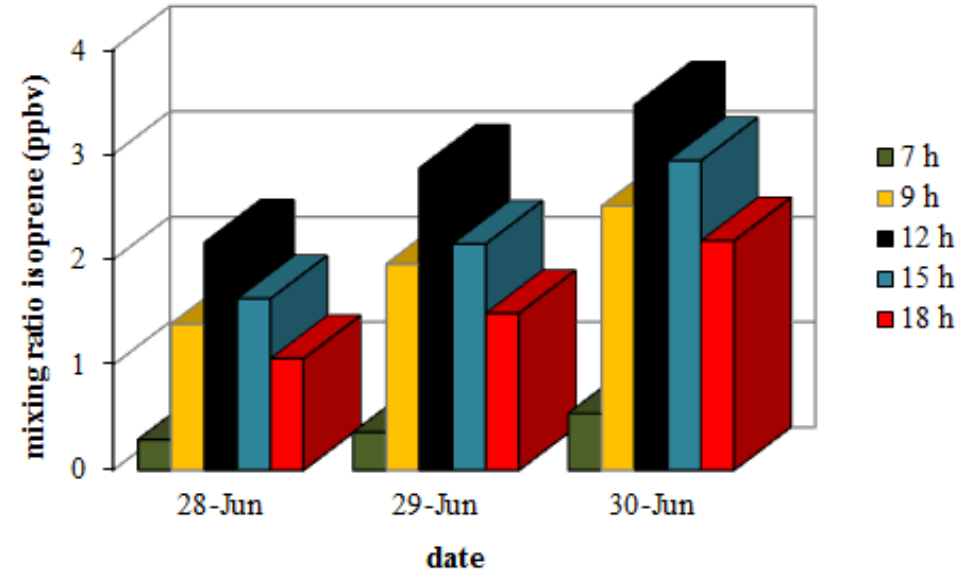

Figure 2 - Mixing ratio of isoprene at each time of collection during the second intensive campaign (2011) in Fibria.

Observe now that the maximum mixing ratios of isoprene were detected again at midday, with higher peak (3,5 ppbv) on June 30, 2011. The second campaign was conducted in winter and at this time of year, the sunset in the region occurs at 17:30 hours, at which time there was a marked decrease in mixing ratio of isoprene to the study period. In the first intensive campaign the maximum isoprene peak was $8,3 \mathrm{ppbv}$ in an amount 4,8 ppbv more than in the second year. The summer months with high air temperature and solar radiation, emission of this gas is larger than in the winter, as noted by Neto et al. (2007).

In this work, the variation is attributed to the ratio of gas with the air temperature (Figures 3 and 4 ) and the photosynthetically active radiation (Figures 5 and 6 ) in the date specified.

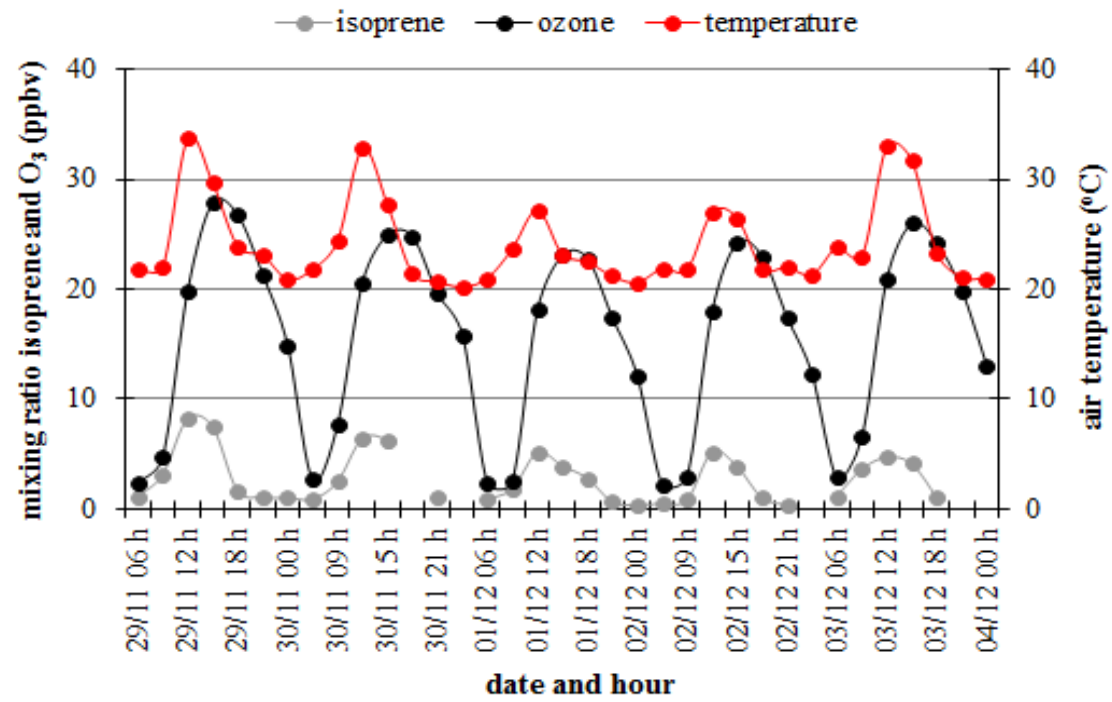

Figure 3 - Mixing ratio of isoprene, ozone and air temperature at each time of collection during the first intensive campaign (2010) in Fibria. 


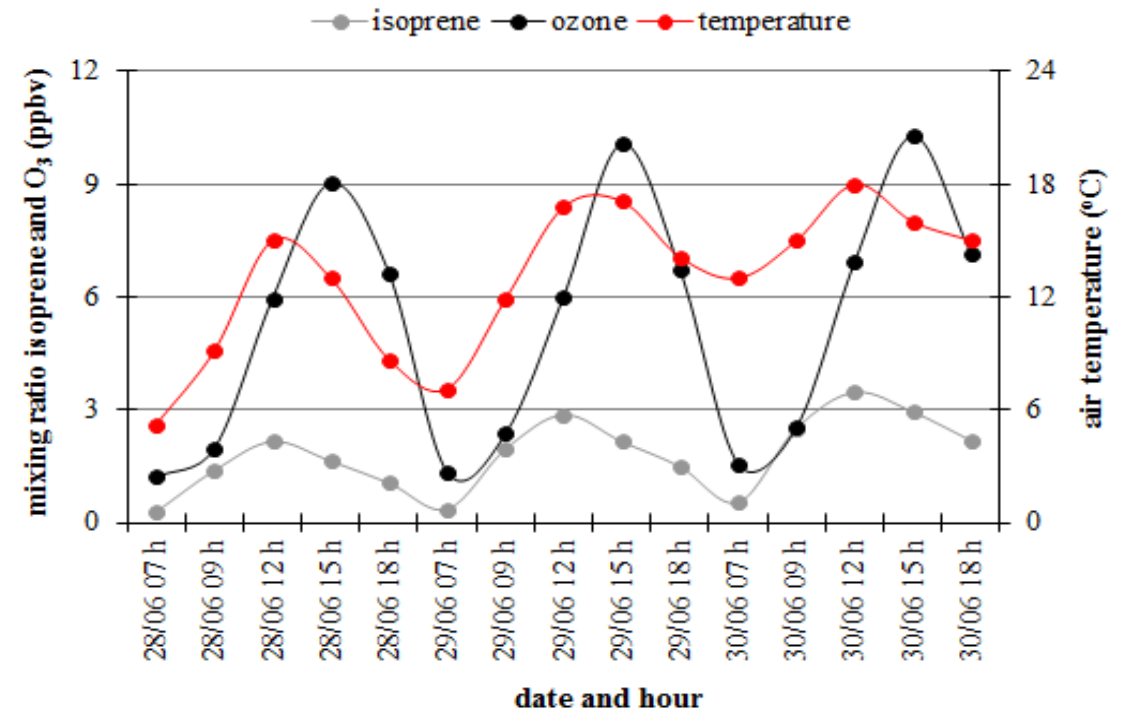

Figure 4 - Mixing ratio of isoprene, ozone and air temperature at each time of collection during the second intensive campaign (2011) in Fibria.

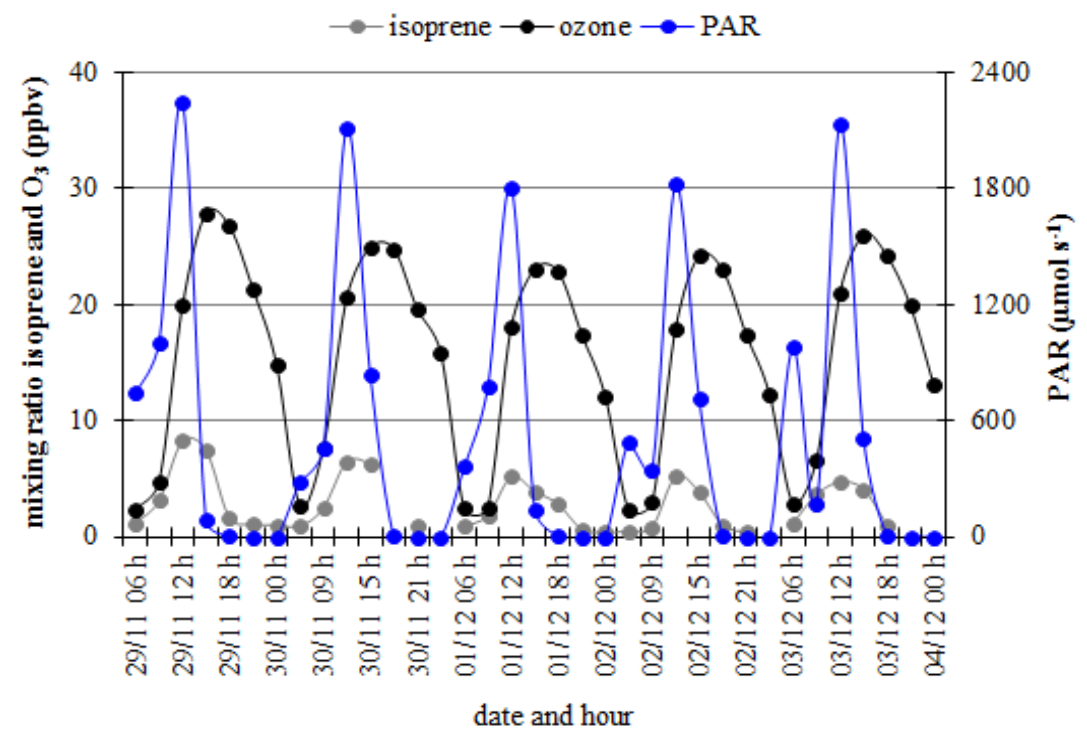

Figure 5 - Mixing ratio of isoprene, ozone and photosynthetically active radiation (PAR) at each time of collection during the first intensive campaign (2010) in Fibria. 


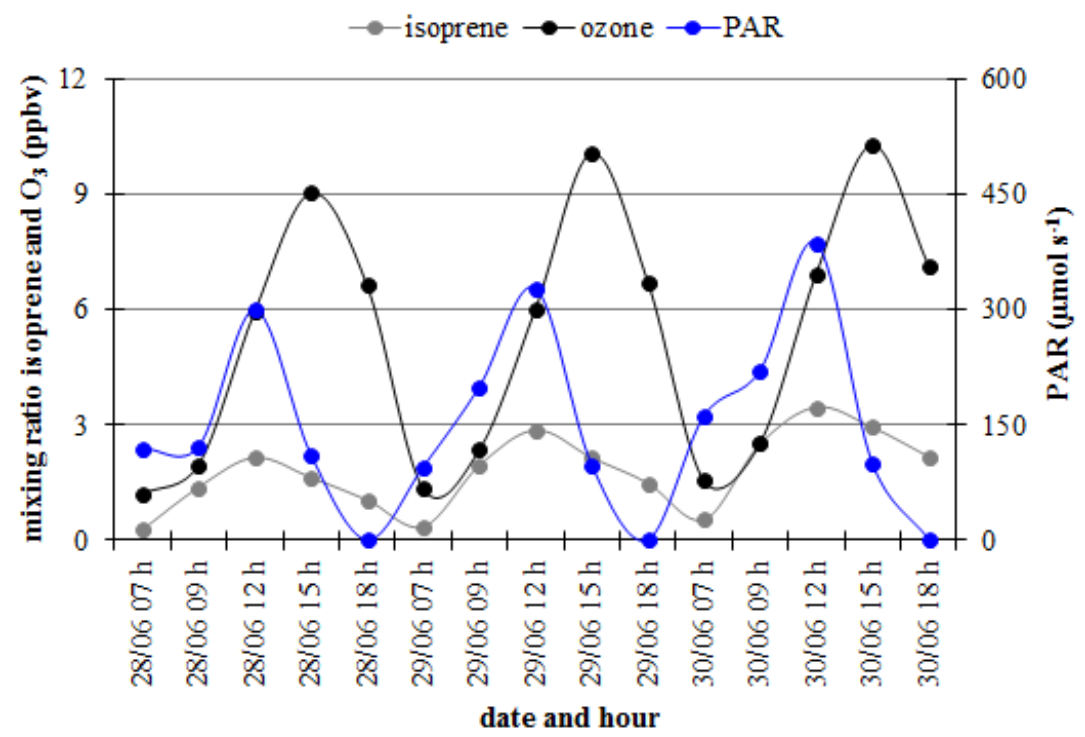

\section{Figure 6 - Mixing ratio of isoprene, ozone and photosynthetically active radiation (PAR) at each time of collection during the second intensive campaign (2011) in Fibria.}

There is a relationship between ozone and isoprene in the region studied, as shown in Figures 3 to 6. Given a static environment and with very low wind (wind speed with an average of less than $0,8 \pm 0,04 \mathrm{~m} \mathrm{~s}^{-1}$ for the first campaign and $1 \pm 0,06 \mathrm{~m} \mathrm{~s}^{-1}$ for the second campaign, data not shown), it is possible to identify that during the evaluation period, the peak ozone showed a delay about two hours from the peak maximum of isoprene, which is justifiable due to the time required for the isoprene and others precursors such as $\mathrm{NO}_{x}$, for example, react in the presence of sunlight and lead to ozone formation. This relationship was also observed by Chameides et al. (1988) that concluded the maximum isoprene concentrations nearly coincident with periods of maximum ozone photochemical production, which makes isoprene oxidation for ozone production more efficient than other $\mathrm{VOC}_{\mathrm{s}}$ such as monoterpenes.

In the first intensive campaign, the maximum peaks of isoprene and ozone were $8,3 \mathrm{ppbv}$ and 27,9 ppbv (Figures 3 and 5), while in the second intensive campaign were smaller, 3,5 ppbv and 10,3 ppbv, respectively (Figures 4 and 6).

In the days of high air temperature and photosynthetically active radiation, the emission of gases was higher as shown in the figures. This emission, in winter 2011 was 65\% lower than in summer 2010, which showed a seasonal variation in isoprene emission by planting eucalyptus.

Rizzo (2006) also observed in the Amazon forest sites that the mixing ratio of isoprene was high during the warmer months, when it reached 29 ppbv, while during the cooler periods the average dropped to 6,9 ppbv.

Due to the influence already known of meteorological factors on the concentration of $\mathrm{VOC}_{s}$, is important that the environmental parameters are known during periods of data collection and analysis of the compounds, so that their influence in the region of study is adequately evaluated. Like Hewitt et al. (1995) who also identified the air temperature and photosynthetically active 
radiation as the two most important factors in the emission of isoprene. In this work it was observed a relationship between higher emissions with warmer periods and with more light available. Guenther et al. (1995) also noted that isoprene emissions increase exponentially with rising temperatures, producing higher isoprene emissions in warmer summer days. Guenther et al. (2000) demonstrated that in addition to temperature, isoprene emissions increase with solar radiation, leading to highest isoprene concentrations during summer midday periods, as observed here. The temperature and solar radiation play an important role in controlling seasonal, year-on-year and spatial variations of isoprene and $\mathrm{VOC}_{\mathrm{s}}$ in general.

\section{CONCLUSION}

The atmosphere of the eucalyptus plantations in the "Vale do Paraíba" can be characterized as clean based on the observed mixing ratio of ozone, the maximum of 27,9 ppbv detected is well below the levels established by CONAMA ( 81,5 ppbv).

As to isoprene, the highest peak in the study period 2010 (8,3 ppbv) and 2011 (3,5 ppbv) always occurred at midday when the temperature and photosynthetic active radiation were higher $\left(33,7^{\circ} \mathrm{C}\right.$ e $2243 \mu \mathrm{mol} \mathrm{s}{ }^{-1}$ e $18^{\circ} \mathrm{C}$ e $387 \mu \mathrm{mol} \mathrm{s}^{-1}$, respectively). The typical climate of the region, with dry winters and hot summers, has a direct influence on plant metabolism by stimulating the synthesis of isoprene, which leads to the emissions of this component.

The peak of ozone always presented a delay of about two hours relative to the isoprene, which can be explained by the fact that the photochemical reactions between the precursors chemicals which lead to the production of ozone require a time interval to take place.

\section{REFERENCES}

CAMPINHOS JR., E. Sustainable plantations of high-yield Eucalyptus trees for production of fiber: the Aracruz case. New Forests, Aracruz, v. 17, pp. 129-143, Jan. 1999.

CETESB. (São Paulo). Relatório de qualidade do ar no Estado de São Paulo. São Paulo: CETESB, 2009. (Série de Relatórios / CETESB).

CHAMEIDES, W. L. et al. The role of biogenic hydrocarbons in urban photochemical smog - Atlanta as a case study. Science, Atlanta, v. 241, p. 1473-1475, Sep. 1988.

FARES, S. et al. Impact of high ozone on isoprene emission, photosynthesis and histology of developing Populus alba leaves directly or indirectly exposed to the pollutant. Physiologia Plantarum, Rome, v. 128, p. 456-465, Oct. 2006.

FARINA, S. C. et al. Modeling global secondary organic aerosol formation and processing with the volatility basis set: implications for anthropogenic secondary organic aerosol. Journal of Geophysical Research, Pittsburgh, v. 115, p. 9202-9219, May, 2010. 
FLYNN, B.; SHIELD, E. Eucalyptus progress in higher value utilization: a global review. Tacoma: Robert Flynn \& Associates, 1999.

FUENTES, J. D. et al. Biogenic hydrocarbons in the atmospheric boundary layer: A review. Bulletin of the American Meteorological Society, Virginia, v. 81, p. 1537-1575, Jul. 2000.

GUENTHER, A.; MONSON, R.; FALL, R. Isoprene and monoterpene emission rate variability: observations with Eucalyptus and emission rate algorithm development. Journal of Geophysical Research, Boulder, v. 96, p. 10799-10808, Jan. 1991.

GUENTHER, A. et al. A global model of natural volatile organic compound emissions. Journal of Geophysical Research, Boulder, v. 100, p. 8873-8892, Nov., 1995.

GUENTHER, A. et al. Natural emissions of nonmethane volatile organic compounds, carbon monoxide and oxides of nitrogen from North America. Atmospheric Environmental, Boulder, v. 34, p. 2205-2230, Jan. 2000.

HARLEY, P. et al. Variation in potential for isoprene emissions among Neotropical forest sites. Global Change Biology, Boulder, v. 10, p. 630-650, Feb. 2004.

HEWITT, C.N. et al. Atmospheric VOCs from Natural Sources. In: HESTER, R. E. et al. (Eds.). Volatile Organic Compounds in the Atmosphere. Cambridge: Royal Society of Chemistry, 1995. p. 17-36 (Issues in Environmental Science and Technology, n. 4).

KESSELMEIER, J. et al. Volatile organic compound emissions in relation to plant carbon fixation and the terrestrial carbon budget. Global Biogeochemical Cycles, Mainz, v. 16, p. 1126-1132, Mar. 2002.

LACK, D. A. et al. Seasonal variability of secondary organic aerosol: A global modeling study. Journal of Geophysical Research, Brisbane, v. 109, p. 3203-3216, Feb. 2004.

LIMA, W. P. Overland Flow and Soil and Nutrient Losses from Eucalyptus Plantations. Piracicaba: IPEF International, 1990.

MORA, A. L.; GARCIA, C. H. A cultura do eucalipto no Brasil. São Paulo: Sociedade Brasileira de Silvicultura, 2000.

NETO, S. V. et al. Inventário de emissões de compostos orgânicos voláteis biogênicos pela floresta de Trás-os-Montes e Alto Douro, Norte de Portugal. Science Forest, Piracicaba, n. 76, p. 35-44, 2007.

PERKINELMER. Application Note: Ozone Precursor Analysis Using the TurboMatrix Thermal Desorption GC System. Shelton, CT: PerkinElmer Life and Analytical Sciences, 2005.

PLACET, M. et al. Emissions Involved in Acidic Deposition Processes. Washington, DC : National Acid Precipitation Assessment Program, Office of the Director; Supt. of Docs., G.P.O., 1990. (Acidic deposition, state of science and technology, rept. 1.).

RIZZO, L. V. Os fluxos turbulentos de partículas e de compostos orgânicos voláteis e a distribuição vertical de aerossóis na baixa troposfera da Amazônia. 2006. Tese (Doutorado em Física). Universidade de São Paulo, São Paulo, 2006. 
SEINFELD, J. H.; PANDIS, S. N. Atmospheric chemistry and physics: from air pollution to climate change. New York: John Wiley \& Sons, 1998.

SHARKEY, T. D.; CHEN, X. Y.; YEH, S. Isoprene increases thermotolerance of fosmidomycin-fed leaves. Plant Physiology, Madison, v. 125, p. 2001-2006, Apr. 2001.

SINGH, H. B.; ZIMMERMAN, P. Atmospheric distributions and sources of nonmethane hydrocarbons. In: NRIAGU, J. Gaseous pollulants: characterizations and cycling. New York: John Wiley \& sons, 1992. p. 177-235. (Advances in Environmental Science and Technology).

SINGH, A. P. et al. Emissions of monoterpene from tropical Indian plant species and assessment of VOC emission from the forest of Haryana state. Atmospheric Pollution Research, New Delhi, v. 2, p. 72-79, Jan. 2011.

TINGEY, D. T.; TURNER, D. P.; WEBER, J. A. Factors controlling the emissions of monoterpenes organic compounds. In: ROY, J.; SHARKEY, T. D.; HOLLAND, E. A. (Ed.). Trace gas emissions by plants. San Diego: Academic Press, 1991. p. 93-115.

USEPA. Determination of Volatile Organic Compounds (VOC ) in Air Collected In SpeciallyPrepared Canisters and Analyzed By Gas Chromatography/Mass Spectrometry (GC/MS). Cincinnati, $\mathrm{OH}$ : Center for Environmental Research Information; Office of Research and Development; U.S. Environmental Protection Agency, 1997. (Compendium Method TO-15).

USEPA. Determination of Volatile Organic Compounds in Ambient Air Using Active Sampling Onto Sorbent Tubes: Cincinnati, $\mathrm{OH}$ : Center for Environmental Research Information; Office of Research and Development; U.S. Environmental Protection Agency, 1999. (Compendium METHOD TO-17).

VOLKAMER, R. et al. Secondary organic aerosol formation from anthropogenic air pollution: Rapid and higher than expected. Geophysical Research Letter, Cambridge, v. 33, p. 17811-17815, Sep. 2006.

WENT, F. W. Blue hazes in the atmosphere. Nature, Saint Louis, v. 187, p. 641-643, Sep. 1960.

WINER, A. M. et al. Hydrocarbon emission from vegetation found in California's Central Valley: Final Report. Riverside, Calif.: Statewide Air Pollution Research Center, University of California, 1989. 328p. 